\title{
An Early Manchu Account of the Western Regions
}

\author{
DAVID BROPHY \\ University of Sydney \\ Volume 14, 2016-2017
}

This article presents a hitherto little-known Manchu work on the Western Regions, i.e., Islamic Central Asia. Dating to 1761, I believe it represents the earliest effort to compile a political and geographic description of this region for Qing officials in Xinjiang. It consists of two sections: (1) an account of the sedentary Muslims of Xinjiang and neighboring Islamic polities; and (2) a description of the Kirghiz. This stand-alone Manchu work was subsequently incorporated into certain rescensions of a more extensive Chinese-language composition, known variously as the Xiyu zhi, Huijiang zhi, or Xiyu dili tushuo. After a brief introduction, the article provides a transcription and translation of the text as it survives in a Moscow manuscript of the Xiyu zhi. This text can be read in conjunction with the section included in the Xiyu dili tushuo to produce a near-complete work.

早期满文西域记述一则

David Brophy 博大卫

悉尼大学

本文介绍一篇迄今鲜有人知的关於西域（即中亚伊斯兰地区）的满文文献。 笔者相信, 这篇问世於1761年的作品, 代表着為清朝新疆官员编纂西域政治 地理形势的最早的一次努力。该作品包含两部分：（1）关於新疆定居穆斯 林族群和周边伊斯兰政权的记载; (2) 关於吉尔吉斯人的描述。这部独立 成书的满文作品此后被吸收到一部更為全面的汉语著作的不同修订版本之 中, 这些版本以《西域志》《回疆志》或《西域地理图说》等题名流传。在 简短的介绍之后, 本文将提供从一部收藏於莫斯科的《西域志》手稿中所辑 录的这篇文献的原文及其译文。这篇文献若与《西域地理图说》中的相关内 容对照阅读，则可以整理出一部近乎完备的作品。 
期滿文西域記述一則

David Brophy 博大衛

悉尼大學

本文介紹一篇迄今鮮有人知的關於西域（即中亞伊斯蘭地區）的滿文文獻。 筆者相信，這篇問世於1761年的作品，代表著為清朝新疆官員編纂西域政治 地理形勢的最早的一次努力。該作品包含兩部分：（1）關於新疆定居穆斯 林族群和週邊伊斯蘭政權的記載; （2）關於吉爾吉斯人的描述。這部獨立 成書的滿文作品此後被吸收到一部更為全面的漢語著作的不同修訂版本之 中, 這些版本以《西域志》《回疆志》或《西域地理圖說》等題名流傳。在 簡短的介紹之后, 本文将提供從一部收藏於莫斯科的《西域志》手稿中所輯 錄的這篇文獻的原文及其译文。这篇文獻若与《西域地理图说》中的相關內 容對照閱讀，則可以整理出一部近乎完备的作品。

\section{Introduction}

Konstantin Adrianovich Skachkov (1821-1883) was a Russian doctor and diplomat who served in China in the mid-nineteenth century. He first went to Beijing in 1848 as a member of the Russian ecclesiastical mission; between 1858 and 1863 he was the tsarist empire's consul in Tarbaghatay (also known in Russian as Chuguchak, Uyghur Chöchäk), before going on to serve in Tianjin and Shanghai. Skachkov was an avid collector of Chinese books and maps, and his archive is now held by the manuscript department (Pashkov House) of the Russian State Library in Moscow.

A sizeable portion of the Skachkov collection consists of official registers and administrative handbooks on Xinjiang, which were almost certainly acquired during his time as consul in Tarbaghatay. Among these is a work called the Xiyu zhi 西域誌 (Gazetteer of the Western Regions), in twelve juan, bound into three books. ${ }^{1}$ This manuscript of the Xiyu zhi is the lengthiest rescencion of a text that is considered to be the first gazetteer-like work to be composed in the wake of the Qing conquest of Xinjiang-i.e., in the 1760s. Besides this version, two shorter rescensions of this work have also come to light, in eight instead of twelve juan. One of these belongs to the library of Sichuan Normal University and has been edited by Ruan Mingdao 阮明道, who gave it the title Xiyu dili tushuo 西域地理圖說. ${ }^{2}$ The other is held in the National Central Library in Taipei and carries the title of Huijiang zhi 回疆志. ${ }^{3}$ This Xiyu zhi family of texts, as I

1. Accession no. 287/445/1-3. For catalog description, see A. I. Melnalksnis and I. K. Glagoleva, Opisanie kitaiskikh rukopisnykh knig i kart iz sobraniia K. A. Skachkova (Moscow: Nauka, 1974), 198-99.

2. Ruan Mingdao, ed., Xiyu dili tushuo zhu 西域地理图说注 (Yanji: Yanbian daxue chubanshe, 1992).

3. Yunggui 永貴, Huijiang zhi, 8 juan (Shunde Li shi, 1893). Scholars have made use of the details that the Xiyu zhi contains, 
will refer to them, was the basis for a heavily edited and more widely circulating Huijiang zhi, also known as the Xinjiang Huibu zhi 新疆回部誌. This has been attributed to the Qing official Yunggui 永貴 (who served in Xinjiang, with interruptions, between 1755 and 1779), with reworkings by Suldei 蘇爾德. On this basis, we might hypothesize that the Xiyu zhi family of texts represents the original work authored by Yunggui. ${ }^{4}$

The precise textual history of the Xiyu zhi is not my concern here. Rather my interest lies with a "text within a text" that it contains. Of the three "long-version" rescensions that have come to light, two of them-the Moscow Xiyu zhi and the Chengdu Xiyu dili tushuo - include a text in Manchu discussing Islamic countries neighboring Xinjiang, as well as the Kirghiz. In the Xiyu dili tushuo, the Manchu is not incorporated into the text, and its editor Ruan Mingdao seems to have treated it as a supplement to Juan 6, which deals with Foreign Barbarians (waiyi 外夷). This is understandable, as the Manchu text here simply consists of a list of Central Asian kingdoms and their sovereigns, as well a list of Kirghiz tribal divisions with the name of each leader (biy) and an estimate of their populations. The Manchu text in the Skachkov Xiyu zhi, by contrast, is a more coherent text, and sits at the head of the entire work as Juan 1. Here the two lists are introduced by narrative sections, entitled (1) "Sectarian Divisions among the Muslims" (Huiren zongpai 回人宗派) and (2) “The Origins of the Various Burut of the Outer Regions” (Waibu ge Bulute yuanpai 外部各布魯特源派).

Although this Manchu text has lacunae of its own, when combined with the Manchu section of the Xiyu dili tushuo we have something approaching a complete text. It is, I believe, substantial enough to be considered a distinct work of unknown authorship, which subsequently became incorporated into some (though not all) copies of the Xiyu $z h i$ and survived only in this form. As for its date of composition, internal evidence points to 1761. It was in this year that the Qing official Haiming 海明 claimed to have found Khoja Burhan al-Din's fugitive son Sarimsaq in Kashgar. Within a few months, however, the court had established that this captive was not the man they were looking for. The text below contains the erroneous information that Sarimsaq had been caught, indicating that it was probably written in the middle of 1761 , following the "capture" of Sarimsaq and before the confusion was cleared up.

As Matthew Mosca has discussed, it was some time before gazetteer-like texts on Xinjiang came to circulate widely in the Qing. ${ }^{5}$ Like the Xiyu zhi itself, this early account of the Muslims and the Kirghiz did not attract much of a readership during the

most recently Kwangmin Kim, Borderland Capitalism: Turkestan Produce, Qing Silver, and the Birth of an Eastern Market (Stanford, Calif.: Stanford University Press, 2016).

4. The most accessible version of the Huijiang zhi is Yunggui and Suldei, Huijiang zhi 回疆志 (1772; repr., Taibei: Chengwen chubanshe, 1968).

5. See Matthew W. Mosca, "Cišii’s Description of Xinjiang: Its Context and Circulation," in Xinjiang in the Context of Central Eurasian Transformations, ed. Shinmen Yasushi, Onuma Takahiro, and David Brophy (Tokyo: Tōyō Bunko, forthcoming). 
eighteenth century. This may come as a surprise, since in some respects it is superior to comparable works. Its account of the peoples of Central Asia and Afghanistan, for example, is considerably more detailed than Cišii's widely copied Xiyu wenjianlu 西 域聞見錄. Similarly, its description of Kirghiz social structure is more informative than the section on the Kirghiz in the Xiyu tuzhi 西域圖志, commissioned at around the same time. ${ }^{6}$ Maybe its defects were felt to outweigh these positive dimensions. Apart from the embarrassing slip on Sarimsaq, it contains other errors. It ascribes, for example, three sons to Khoja Ahmad (instead of two). Or it may also be the case that it consigned itself to the margins of Qing scholarship on the Western Regions by contradicting official works such as the Xiyu tuzhi. To take the most interesting example of these discrepancies, while the Xiyu tuzhi adopts the notion of "Eastern" and "Western" wings of the Kirghiz, here the dual structure is described in terms of a north/south division.

This text is not entirely unkown to scholarship. There exists an unpublished Russian translation of its second section (on the Kirghiz), made in the 1970s by G. P. Suprunenko. ${ }^{7}$ References to the Xiyu zhis distinctive account of Kirghiz origins can therefore be found in Russian-language scholarship. ${ }^{8}$ A copy of this translation is held in the Archive of the Academy of Sciences in Kirghizstan, and has recently been made available online. Looking at this text, it is clear that Suprunenko was translating not from the Manchu original but from the interlinear Chinese gloss that accompanies the Manchu. To my knowledge, the first part of this work, on the sedentary Muslims of Xinjiang, has not yet been studied.

Here I provide a transcription of Juan 1 the Xiyu zhi and a translation, with a preliminary effort to identify the places and individuals mentioned. In the translation, where possible I have tried to restore names and places to an appropriate Arabic/Turkic form; otherwise I have left them as given in the Manchu. While I have made occasional reference to the Xiyu dili tushuo (XYDLTS), I have not fully integrated the two texts. This article should therefore be read in conjunction with Onuma Takahiro's edition and Japanese translation of that section of the Manchu text. ${ }^{9}$

The following symbols are used in the transcription and translation:

6. Fu-heng 傅恆, comp., Qinding huangyu Xiyu tuzhi 欽定皇舆西域圖志 (Taibei: Wenhai chubanshe, 1970), juan 45. For a French translation of the section on the Kirghiz, see Camille Imbault-Huart, Recueil de documents sur l'Asie Centrale (Paris: Ernest Leroux, 1881).

7. G. P. Suprunenko, Materialy iz kitaiskikh istochnikov po istorii kirgizov XVIII-nachalo XIX vv. 1976 (Rukopisnyi fond Natsional'noi Akademii nauk Kyrgyzskoi Respubliki 5179), 78-83. Accessible online at: http://manuscript.lib.kg/pукопись/ Мат-лы-из-китайских-источников-истории-кыргXVIII-XVX в .

8. For example, A. M. Mokeev, "Dual'naia etnopoliticheskaia organizatsiia kyrgyzov na Tian'-Shane v XVI - seredine XVIII v.," Tiurkologicheskii sbornik 2007-2008 (2009): 258-72.

9. Onuma Takahiro 小沼孝博, “'Saiiki chiri zusetsu’ shoshū no chūō Ajia shobu ni kanren suru Manbun kiji ni tsuite” 『西 域地理図説』所収の中央アジア諸部に関連する満文記事について, in Min Shin ryōchō no 'han' seisaku no hikaku $k e n k y \bar{u}$ 明-清両朝の「藩」政策の比較研究, ed. Kataoka Kazutada 片岡一忠 (Tsukuba: Tsukuba University, 2004). 
() Explanatory notes in the original

$<>$ Interlinear insertions in the original

[] Editorial additions

$\wedge$ Taitou (respectful elevation of the text)

\section{Transcription}

${ }^{[1]}<$ 回人宗派 $>$

seibeni Hoise i gubci urse. meimeni feniyen ci niyalma dalafi. babade son son i tehe bicibe. Kaburdin Han uherilembihe. Kaburdin Han dubehe amala. ce an i fakcashūn ohobi. emu tanggū juwan funcere aniyai onggolo. Buhar (Buhar serengge Kaburdin Han i fukjin tehe aiman i gebu. Kasigar i wargi ilan biyai on i tubade bi. ba onco. niyalma geren. babai Hoise gemu Buhar baci uksalafi tucikengge.) ba i Yusub gebungge bayan niyalma. Hoise nomon de ${ }^{[2]}$ sain bime ceni enduri paihampar Mahamdimin i omolo ofi. Hoise se gemu hojo (hojo serengge looye sembi.) seme kundulembi. umai tacin be dasara. tacihiyan be selgiyere. baita be lashalara niyalma waka.

Yusub. Buhar baci Kasigar de gurinjifi ilan jui banjiha. emke gebu Apa. emke gebu Kermet. emke gebu Ana It. ${ }^{10}$ Apa i jui Yayai. Yerkiyang ni fe hojo Mamadimin be belefi. Mamadimin i ajige jui Akbaši be hojo obuha. ${ }^{[3]}$ sirame Yayai. horon cukuhe ofi. Akbasai. ini ama i karu be gaime Yayai be waha de. geren Burut (Burut serengge alin i dolo nuktere Hoise.) Hoise i ba be kicere gūnin turibufi. Akbasi i fiktu be baime. imbe karmame besergen tehe gungge niyalma be. soktoho hūsun de turgun akū waha seme. Burut sebe labdu guilefi. Akbasi be nungnehe. gelhun akū besergen tehekū. ambakan bek (bek serengge Hoise i hafan.) sei emgi baita icihiyaha.

Hoise sei gūnin ${ }^{[4]}$ gemu daharakū. jing toktohon akū dekderšeme bisire de Halmak (Hoise se Ūlet be Halmak sembi.) Tsewang Rabtan. (Tsewang Rabtan serengge Ület sei fe han.) jing Hoise i babe hiracame bifi. cohome cooha deribufi. Burut sebe bašafi. ambakan bek sebe dalabufi funde baita icihiyabume. ba na i alban be toktobuha. Yayai i enen be geli baita dekdeburahū seme. Yayai i jui Ahamad. ini boigon anggala. fejergi niyalma be suwaliyame. Ili (Ili serengge Tsewang Rabtan i nuktere ba.) de ${ }^{[5]}$ gamafi. usin taribume tebuhe.

Ahamad Ili bade ilan jui banjiha. emke gebu Buranidun. emke gebu Hojijan. emke gebu Kecikhojom. Ahamad i beye wajiha amala. ese Hoise be dendeme dalaha. Buranidun nomon de sain bime. ibagan bušuku afara tarni. edun aga dekdebure yada fadame mutembi. tuttu geren gemu Buranidun be. enduri Paihampar Mahamdimin i enen ofi. geren be karmatara baita muterekūngge akū seme. inu ${ }^{[6]}$ enduri obufi kundulehe.

10. The Chinese gloss has read this element as Iol (有勒). On the assumption that the underlying name here is Inayat, I prefer to read $I t$. 
Tsewang Rabtan dubehe amala. tesu gargan i jaisang (jaisang serengge ceni ujulaha ambasai tušan.) Dawaci se. ishunde besergen temšendure jakade. Amursana sere jaisang. $\wedge$ enduringge ejen de dahame dosifi. dara cooha baire de. ^han ejen. ceni facuhūraha be $\wedge$ giljame. geren ergengge i jocibure be gosime. funde ${ }^{[7]}$ amba cooha unggifi. Dawaci sebe jafaha. Amursana se <niohe i banin be naranggi waliyarakū. emhun bigan i hutui da oki seme> abkai kesi be šuwe urgedefi ubašaha turgunde. amba cooha dailanafi Ili be necihiyeleme toktobuha.

$\wedge$ enduringge han Hoise sei goidame samsibuha be ^jilame. Buranidun se. jai tabcilabuhale Hoise. Burut sebe gemu da bade guribuhe. ede Buranidun beye Kasigar i han oho. Hojijan inu Yerkiyang ni han oho bime. gelhun akū ${ }^{[8]} \wedge$ abkai gurun i dasame banjibuha kesi be cishūlafi. ubašaha hūlha Ūlet Šaras. Mahūs sei sunja tanggū funcere boigon be halbume bibufi. hanci akdara niyalma ome. ceni hūsun de Hoise i geren be gidašame deribuhe. beyei yabuha waka de iseleme. jiyanggiyūn Yarhašan sei tucibuha hūlhasa be fargara elcin Amindao sebe nungnefi ubašaha. jiyanggiyūn Jaohūi se cooha gaifi. hūlha Buranidun sebe Badakšan (Badakšan serengge Kasigar i wargi ${ }^{[9]}$ julergi juwe biyai on i dubede bisire emu Hoise i aiman.) de isitala farganafi gisabuha.

Hoise ba i Kasigar. Yerkiyang ni jergi jakūn amba gebungge hoton be dahabufi. amba baita šanggaha. julgeci ebsi ursu akū ferguwecuke gungge mutebuhe ofi. Buranidun i emu uksura. ceni beye tucike sekiyen be. booi durungga de nirufi. geren aiman i Hoise i dalaha niyalmai gebu. tehe ba na. hoton i gebu be. suwaliyame murušeme ${ }^{[10]}$ baicafi amala faksalame arafi ejihe.

${ }^{[12]}$ booi durungga de bisire. emu niyalma. juwe hacin gebulehengge. gemu nenehei ceni han wang ofi. gebui wesihun fungnehen hergen nonggihengge bi. hartungga urse ceni enduri saisa i gebu. nomon i sain gisun be jorifi. wesihuleme colo tukiyecerengge inu bi. tuttu durungga de. fungnehen bisirengge be. gebui dergide araha ci tulgiyen. colo bisirengge be amala araha.

${ }^{[13]}$ Apa i colo Anayat.

Hojomemin i colo Molohojom.

Musa i colo Hojomunus.

Alii i colo Alaihojo.

Yayai colo Yahaya.

Ahamat i colo Hoyahaman.

Mamadimin i colo Mahamet.

Arib i colo Sultan.

[14] durungga de araha ceni gebui fejile. ememungge fulgiyan fuka kūwarahangge. gemu musei ^amba cooha isinjifi. jafame baha. beye baime jihe. amala baicame tucifi gemun hecen de benehe. fifame tucifi tomoro ba baime ukcahangge be dahame. meimeni turgun be tucibume amala faidame araha ci tulgiyen. Buranidun. Hojijan se. mu- 
sede gisabuha. funcehe urse. gemu meni isinjire onggolo aifini akū ohongge be dahame. esei gebui fejergi de untuhun sulabuhabi.

Cung Aidzim. Ana Aidzim. Dakis Aidzim. ${ }^{[15]}$ ere ilan be. Fude se Badakšan ci jafame gajifi gemun hecen de benebuhebi.

Mamahojom. ere emke. Turdu be dahalame gemun hecen de dosika.

Musa. Erib. ere juwe be jiyanggiyūn Fude se. Isil Kul bade afame jafame bahafi gemun hecen de benebuhebi.

Eseyen. Mamut. ${ }^{[16]}$ Parsa. Baba. ere duin be Jiyanggiyūn Jaohoi se Hoohan ci baicame gajifi. gemun hecen de benebuhe.

Turdu. Akbotu. ere juwe be. Sayak Sarbagaši aiman i Burut Mamuhūli i nukte ci beye baime jifi gemun hecen de genehe.

Samsak. ere emke be amban Haiming Kasigar ci baicame tucibufi. gemun hecen de benebuhe.

${ }^{[17]}$ Asim. Abduhalik. Bahawedin. ere ilan be. amban Sinju Badakšan ci baicame gajifi. gemun hecen de benebuhe.

Mahamdimin. ere emke. Badakšan de tomoho bihe. amala ukcafi casi Imamul sere aiman de genehe.

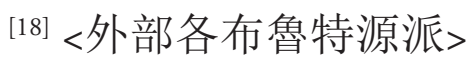

Burut serengge alin i dolo nuktere Hoise. etuku adu. hoton tere Hoise seci encu bicibe. terei doro emu adali. banjire were arbun muru. Hoise seci majige encu. ceni sekiyen be fujurulaci. daci inu Buhar bai niyalma bihe. niyalma geren ba isheliyen. teme baktarakū dade. lakcan akū ba na be temšere dain dekdeme ofi. ce gemu buya urse. facuhūn i jocibure gasacun dosomburakū de ${ }^{[19]}$ son son i samsifi. alin i dolo majige morin ulha de akdame. abalame angga hetumbume. ne ilan tanggū gūsin funcere aniya ohobi.

tere forgon. ese gemu facuhūn be jailame. alin i dolo tomonohongge. cun cun i labdu ofi. ishunde abalame baktarakū de. ceni dolo geli ba na be temšendure. eture jaka tongga bahara de. dulere hūda be durinure tacin banjinafi. eherehei ishunde ${ }^{[20]}$ tusa baharakū oho turgunde. juwe tanggū orin funcere aniyai onggolo. ce uhei hebešeme hūwaliyafi. boigon anggala be neigen hūwalame. juwe meyen dendefi. bayan ningge be sonjome. juwe da kundulefi. meni meni ejelehe ba na muke alin be jorime. julergi amargi juwe gargan faksalafi. julergingge be Togosohol. amargingge be Kergekis seme gebulefi. meimeni dendehe tesu gargan i dorgi. ceni tuktan ${ }^{[21]}$ alin dosire fonde acaha baksan be fakcaburakū. daci isinaha. alin holoi ongko mukei isire be tuwame. encu encu nukte dendefi. nuktere ba na alin i gebu be alhüdame. teisu teisu aiman gebulefi. beri beri dendehe jecen be dabanaburakū. tesu dolo i ishunde nungnere be nakaha.

tereci majige šošohon baha bicibe. ceni Hoise i nomon i tacin sibkirakū de. fejergi urse naranggi ${ }^{[22]}$ bargiyatashūn akū bime. akdun hūwaliyasun yaburakū ofi. kemuni 
jugūn jugūn be hetureme. amasi julesi yabure Hoise i hūdai urse be tosome hetu aisi be kicere jakade. aiman aiman i Hoise sei hūdašara jugūn be hanggabufi hūda be hafumburakū turgunde. Hoise se teni labdu guilefi. cembe bašame tabcilame deribuhebi. ede kimutulefi. Burut se bolori dari morin ulhai tarhūn ucuri be amcame. geren be isafi. alin tucifi. Hoise sebe emgeri ${ }^{[23]}$ tabcilaha manggi. baha olji be tuweri hetumbi.

Hoise se banitai nomhon eberi. ba i ongko geli juken. morin i hūsun baharakū de. ja i ceni baru bakcilarakū. ememungge inu feniyelefi karu gaicibe. damu Burut se alin de ureshūn. beiguwen de taciha. morin ulha sehe seme yooni nimanggi juhe de mangga. Hoise sei nikenehe be safi. tuktan eljerakū. arbungga bade niyalma buksifi. komso cooha tucifi sujame. aici kes sere alin. aici lakcaha šumin gobi. ${ }^{[24]}$ akūci hafarhūn isheliyen holo de yarkiyame dosimbuha manggi. emgeri hafitame afara ohode. abalara adali hūsun fayarakū bata be cukubume gidabumbime. hono uthai gisaburakū. damu sain hehesi be bibufi. funcehe feye jadaha. lete lata yafagalahangge be. kemuni amasi da bade ukcambufi. ceni sirame aniyai tabcilara usin jeku be taribubumbi.

Hoise se umesi sotarabuha manggi. uthai ambarame dailanacibe. hūsun mohotolo aššafi. manggai kimun fulgara teile. umai tusa ${ }^{[25]}$ baharakū de. enteheme amba cooha ilime muterakū ofi. bolori dari emgeri tabcilabure be kooli obuhai jihe. damu Burut sei jihe be sabume. ekšeme saksime sibe de dosifi. tuwakiyarangge sain oci. feye yeru be fekuteburakū. tulergi jekui jergi jaka be gaifi gamaci jabšan sembihe.

$\wedge$ dulimbai gurun Hoise be tohorombume dahabuha ci ebsi. gemu ^abkai fejergi be uherilehe ejen i albatu oho seme. Burut se ${ }^{[2]}$ gelhun akū latunjihakū bime. inu teisu teisu $\wedge^{\wedge}$ wen de dahafi. uju alibume hungkereme dosika. fafun šajin be dahame. an be tuwakiyame ginggun ijishūn i ^ enduringgei forgon de urgun sebjen i banjire hūturi be alime. durire tabcilara be eteme halaha. ne dorgi tulergi yabure hūdai ${ }^{[27]}$ amba jugūn be šuwe bolgo sain i hafumbuha bime. wei nukte be darici. hono tuwašatame dulemburengge.

^enduringge ejen i gosin wen. abkai fejergi be akūmbufi. banin bisirele ergese be sain ici forobume dasah[a]kūngge akū be iletuleci ombi. damu umesi goro nimanggi alin i koco wai de tomome bisire. udu ajige aiman i urse. ceni feniyen banjinarakū. geren ${ }^{[28]}$ eshun aiman i bakcin waka be geleme. gelhun akū jecen ci tucifi cuwangname yaburakū. ne an i tesu nuktere alin holo de bisire majige ongko be nikeme. mukei sekiyen be dahame hetumbume somimbi. bade umai be tucirakū ofi. hoise se inu tubade generakū. geren aiman i amba jugūn de holbobuhakū bime. ceni banjirengge geli yadahūn ofi. cende inu dain akū. tuttu ${ }^{[29]}$ bicibe. ce gemu Hoise Burut sei tehe ba na i adame bisire alin holoi daniyan wai de suwaliyaganjame tehe. $<$ Burut se usin tarirakū. akdahangge Hoise i jeku. gebu [sic] abalame baha gurgu i yali be jembi. sukū be edumbi. fuseke morin igan honin be uncafi Hoise jeku boso be hūlašame banjimbi. yaka aiman i fusen juken. jeku boso hūlašara jaka baharakū de esei jendu jifi tabcilara be enteheme akdulaci ojoro bime.

ceni dolo ishunde abalame baktarakū de isinaha manggi. ce ishūnde facuhūn dek- 
defi aitubure be> dahame. Burut i julergi amargi juwe gargan de baktambuha aiman i da sekiyen. geren dalaha bii (bii serengge hafan i gebu) i gebu be. tucibume arafi. murušeme fujurulaha boigon i ton be ilgame faksalame amala arafi ejehe.

${ }^{[30]}[\ldots]$ Jumgal de usin tarime nuktembi.

Mingilha i juwe tanggū funcere boigon. Tiyeriyek de usin tarime nuktembi. Temuryan i niyalma. emu tanggū funcere boigon. Tuyuhuyar de usin tarime nuktembi.

Sarbagaši Burut Polat ${ }^{11}$ i niyalma. juwe minggan isire boigon. Yucutaši Maral ${ }^{12}$ de usin tarime nuktembi.

Buhei Burut Cirikci i niyalma. ninggun tanggū funcere boigon. ${ }^{[31]}$ Yucuheike de usin tarime. juwari nuktembi. Šargarlam de usin tarime tuweri hetumbi. Yambulak de ulha adulambi.

Bagaši Burut Bayastan i niyalma. sunja tanggū isire boigon. Maral ${ }^{13}$ de usin tarime nuktembi.

Baskis Burut Murat i niyalma. duin tanggū isire boigon. Alabugu de usin tarim nuktembi.

Monggoldor Burut Ecibai i niyalma. ilan tanggū funcere boigon. Borondu de usin tarime nuktembi.

${ }^{[32]}$ Juncirik Burut Jaomarat i niyalma. ninggun tanggū funcere boigon. Šadzang i niyalma. duin tanggū isire boigon. Otbaši de usin tarime nuktembi. erei harangga juwe aiman i dorgi. Bisitamagan Burut Yoldubai i niyalma. ilan tanggū funcere boigon. Baši Su de usin tarime nuktembi. Asak Burut Beimet i niyalma. juwe tanggū funcere boigon. Ombisitan de usin tarime nuktembi.

[33] Solton Burut Yamansara i niyalma. ninggun tanggū isire boigon. Susamar de usin tarime nuktembi. Niša i niyalma. ilan tanggū funcere boigon. Karagun de usin tarime nuktembi.

Hūšici Burut Narabatu i niyalma. ninggun tanggū funcere boigon. Ebeidule i niyalma. ilan tanggū funcere boigon. Jergital. Alaktuhun. Kaidar An. On Arcak de usin tarime nuktembi. erei harangga ${ }^{[34]}$ Yowasi Burut Coboo i niyalma. juwe tanggū isire boigon. Aksai de usin tarime nuktembi.

Hetaikuci Burut Jiyambek i niyalma. juwe minggan isire boigon. Kunci. Cuitala de usin tarime nuktembi. erei harangga ilan aiman i dorgi. Kušuci Burut Maitak i niyalma. emu minggan sunja tanggū funcere boigon. Talas Aktubak de usin tarime nuktembi. Hetai Burut Haraboldu i niyalma. emu minggan juwe tanggū funcere boigon. ${ }^{[35]}$ Talas Karabula. Yurumaral. Kunci de usin tarime nuktembi.

Saru Burut Hojohuli i niyalma. sunja tanggū funcere boigon. Burut Šabatu i ni-

11. XYDLTS: Bolot.

12. XYDLTS: Ketmal.

13. XYDLTS: Yurumaral. 
yalma. duin tanggū funcere boigon. Jambala i niyalma. duin tanggū isire boigon. Talas i Kumušitak de usin tarime nuktembi.

Edegene Burut i Ajibii i niyalma. jakūn tanggū isire boigon. Oos hoton de tuweri hetumbi. Wama. Muyun. Guidahuna. Jumbais de usin tarime. ulha adulame. juwari nuktembi. ${ }^{[36]}$ erei harangga jakūn aiman i dorgi.

Hurumši Burut Oljitai i niyalma. emu minggan isire boigon. Tinibek i niyalma. duin tanggū isire boigon. Esgen gašan de usin tarime nuktembi.

Giyoori Burut Hudzibii i niyalma. sunja tanggū isire boigon. K’orpa gašan de usin tarime nuktembi.

Ardamunak Burut Atabotu i niyalma. ilan tanggū isire boigon. ${ }^{[37]}$ Juma i niyalma. juwe tanggū isire boigon. Alimtube. Ajibek. Manak de usin tarime nuktembi.

Bojire Burut Atnahuli i niyalma. ilan tanggū isire boigon. Baihudzi i niyalma. juwe tanggū isire boigon. Arman gašan de usin tarime tuweri hetumbi. Kairma de usin tarime juwari nuktembi.

Bergei Burut Hūrbantai i niyalma. alin tanggū funcere boigon.

${ }^{[38]}[\ldots]$ ere jugūn i amargi alin i dolo. geli julergi gargangga bimbime. julergi alin i dolo. geli amargi gargangga bi. ubabe kimcime yargiyalaci. gemu ceni neneme gargan dentehe amala. fejergi urse Hoise i hūda be tabcilafi. karu gaime baihanara harangga data baicame jafara be jailame. balai gurinume tefi goidaha turgunde. hethe ilimbahafi da bade marihakū. te uthai ishunde. suwaliyaganjame tehebi sembi. damu esebe uherilehe ujui aiman. ne kemuni da dendehe bade nuktehe be dahame. ${ }^{[39]}$ amala arame tucibufi jihe.

julergi Togosohol gebungge gargan de holbobuha geren ujulaha aiman. Kibcak, [__ ], Karatigin, Bagaši, Edegene, Boire, Naiman, Giyoori, Ti’it

${ }^{[40]}$ amargi Kergekis gebungge gargan de holbobuha geren ujulaha aiman. Siyak Sarbagaši, Hetaikuci, Saru, Hūšici, Monggoldor, Solton, Yuwasi, Mondos, Baskis, Kušuci, Cirik

\section{Translation}

\section{Sectarian Divisions among the Muslims}

Formerly the various Muslim nations were led by different people, and when they gradually settled in various places, Kaburdin Khan ruled them. ${ }^{14}$ After Kaburdin Khan died, they all became dispersed as before. More than a hundred and ten years ago, a wealthy

14. My only tentative guess at this name is Qamar al-Din, a Dughlat amir who rivaled Amir Temür for control of Moghulistan in the fifteenth century. See Hodong Kim, "The Early History of the Moghul Nomads: The Legacy of the Chaghatai Khanate," in The Mongol Empire and Its Legacy, ed. Reuven Amitai-Press and David O. Morgan (Leiden: Brill, 1999), 290-318. 
man from Bukhara (Bukhara is the name of the region where Kaburdin Khan originally settled. It is three month's journey to the west of Kashgar. The land is broad, with a large population. The Muslims of every place all originate from Bukhara) by the name of Yusuf, ${ }^{15}$ owing to the fact that he was well-versed in the Muslim scriptures and was the descendent of their Holy Payghambar Muhammad Emin, was revered by all the Muslims as their khoja (khoja means "elder"). He was not at all someone who could reform the customs, promulgate the teachings, or take charge of affairs.

Yusuf moved from Bukhara to Kashgar. He had three sons: one was called Apaq, one was called Karamat, one was called 'Inayat. ${ }^{16}$ Apaq had a son called Yahya. He assassinated the old khoja of Yarkand, Muhammad Emin, and appointed Muhammad Emin's son Aqbash as khoja. ${ }^{17}$ Later, when Yahyya's authority weakened, Aqbash took revenge for his father and killed Yahya. At this, all the Burut (the Burut are Muslims who nomadise in the mountains) set their sights on the Muslim territory. They took [the actions of] Aqbash as a pretext, saying that in a drunken rage for no good reason he had killed a meritorious man who had assumed the throne and was protecting him. They summoned many Burut and murdered Aqbash. They did not dare to take the throne, so the leading begs managed affairs jointly (a beg is a Muslim official).

The Muslims did not reconcile themselves to this [situation]. At precisely this time, when there was instability and mobilisation going on, the Qalmaq (the Muslims called the Ölöd "Qalmaq") Tsewang Rabtan (Tsewang Rabtan is the former khan of the Ölöd) was eyeing the Muslim region closely. He led a huge army and drove off the Burut, then brought the elite begs to submission and had them rule on his behalf, fixing the amount of tribute for the territory. Because he was worried that Yahya's offspring might provoke unrest, he rounded up Yahyàs son Ahmad, his family and followers, and brought them to Ili (Ili was the location of Tsewang Rabtan's pasturage). He settled them there growing crops.

Ahmad had three sons in Ili. The first was named Burhan al-Din, one was called Khoja Jahan, and one was called Kichik Khojam. ${ }^{18}$ When Ahmad passed away, they divided up and led the Muslims. Burhan al-Din was knowledgable in the scriptures. He knew the spells to summon monsters and spirits, and the yada magic to invoke rain and wind. Thus everyone worshipped Burhan al-Din as a holy man, because he was a descendent of the holy payghambar, ${ }^{19}$ and there was nothing he could not do to protect the community.

15. This is the Naqshbandi shaykh Muhammad Yusuf, grandson of Makhdum-i A'zam, who was active in the Tarim Basin in the first half of the seventeenth century. On him, see Joseph F. Fletcher, "The Naqshbandiyya in Northwest China” ed. Jonathan N. Lipman, in Studies on Chinese and Islamic Inner Asia, ed. Beatrice Forbes Manz (Aldershot: Variorum, 1995).

16. Here, and in the list below, the narrative is confusing the names and nicknames (laqab) of these White Mountain khojas. Karamat[ullah] and 'Inayat[ullah] are two desginations for the same individual, Yusuf's second son. Yusuf's third son is usually referred to as Wilayatullah/Qana atullah.

17. Aqbash Khan, a Chaghatayid who took the throne in Yarkand in 1696.

18. This is an error. Kichik Khojam ("the younger khoja") was Khoja Jahan's epithet.

19. That is, the prophet (Persian payghämbar) Muhammad. 
When Tsewang Rabtan died, because the jaisangs (jaisang is the title of the leading officials) of his tribe such as Dabachi were vying for the throne among themselves, a jaisang by the name of Amursana submitted to the Holy Ejen and requested troops in support. The Khan Ejen forgave the fact that he had rebelled, and since he took pity on any living creature that was suffering an injury, he sent the Imperial Army out at [Amursana's] behest and captured Dabachi and the others. In the end, because Amursana was unable to give up his wolfish essence, and desired to become the sole leader of the wandering ghosts, he completely turned his back on the emperor's grace and rebelled. Thereupon the Imperial Army advanced and pacified Ili.

The Heavenly Khan took pity on the Muslims' long period of disunity, and he returned Burhan al-Din, along with all the Muslims who had been kidnapped, as well as the Burut, to their native lands. Thus Burhan al-Din himself became khan in Kashgar, while Khoja Jahan became khan in Yarkand. They dared to spurn the grace that the heavenly dynasty had shown them in repatriating them and sheltered more than five hundred households of Ölöd brigands belonging to the Sharas and Makhus [otogs]. These became [Burhan al-Din and Khoja Jahan's] close confidants, and drawing on their strength they set out to subjugate all the Muslims. Aghast at the sin they had thus committed, ${ }^{20}$ they murdered the emissary Amindao, whom General Yarhašan had dispatched in order to chase the bandits, and went into rebellion. General Jaohūi led an army and pursued the rebel Burhan al-Din and the others as far as Badakhshan (Badakhshan is a Muslim territory that lies at the end of a two-month journey to the southwest of Kashgar) and wiped them out.

Having thus pacified the so-called Eight Cities of the Muslims, including Kashgar and Yarkand, the primary task was achieved. As this was an astonishing accomplishment, the like of which has not been seen from ancient times until now, we have set out Burhan al-Din's clan and their family origins in a genealogical chart, and together with this we have investigated in broad outline the identities of the Muslim chieftains of the various territories, the locations in which they reside, and the names of the cities. Below we have listed these and added written annotations.

The names of people in this $\mathrm{chart}^{21}$ are given in two forms. There are some who had previously been aristocrats and had titles added to their names, and there are some whom the common people praised with respectful epithets indicating their clerical rank, or with some auspicious religious words. Thus in the chart, for those who have aristocratic titles, they are indicated above the name, and for those who have honorary epithets, they are written afterwards.

20. Dictionary definitions of the verb iselembi (e.g. Jerry Norman, A Comprehensive Manchu-English Dictionary [Cambridge, Mass.: Harvard University Asia Center, 2013], 200: "to oppose steadfastly, to defy, to resist") are an awkward fit in this context. The Chinese gloss (懼怕) has evidently interpreted the word as isembi, and my translation follows this reading. 21. This evidently refers to an earlier layout, which is not reflected in this manuscript. 


$\begin{array}{ll}\text { Apaq } & \text { His epithet is 'Inayat } \\ \text { Khoja Emin } & \text { His epithet is Mulla Khojam } \\ \text { Musa } & \text { His epithet is Khoja Yunus } \\ \text { 'Ali } & \text { His epithet is 'Ali Khoja } \\ \text { Yahya } & \text { His epithet is Yahya } \\ \text { Ahmad } & \text { His epithet is Khoja Ahmad } \\ \text { Muhammad Emin } & \text { His epithet is Muhammad } \\ \text { 'Arif } & \text { His epithet is Sulțan }\end{array}$

In this chart, below the names, some have been circled in red. These were either captured when our Imperial Army advanced, or themselves came to submit. Afterwards, they were interrogated and sent to the capital city. In the case of those who absconded and came back [to Qing territory] seeking a place to settle, their various reasons [for doing so] have been clarified and written in line with them. Apart from this, Burhan al-Din and Khoja Jahan were exterminated by our army, and the rest of their troops had [already] been routed prior to our advance, so we have left a blank space beneath their names.

Chong Aghacham, Ana Aghacham, and Dakis Aghacham: Fude brought these three back from Badakhshan and sent them to the capital. ${ }^{22}$

Muhammad Khojam: This individual followed Turdu and went to the capital. ${ }^{23}$

Musa and 'Arif: General Fude attacked and captured these two at Yashïl Köl and sent them to the capital.

Husayn, Mạ̣mud, Parsa, Baba: General Jaohūi scouted these four out in Kokand and sent them to the capital. ${ }^{24}$

Turdu and Aqbuta: These two came seeking refuge from the territory of the Burut Mahmud Qulï of the Sayaq and Saribaghïsh and went to the capital.

22. Baha' al-Din's three wives were named Zulaykha, Badam, and Erke Jan. See David Brophy, "High Asia and the High Qing: Persian Letters in the Beijing Archives," in No Tapping around Philology: A Festschrift for Wheeler McIntosh Thackston Jr.'s 70th Birthday, ed. Alireza Korangy and Daniel J. Sheffield (Wiesbaden: Harrassowitz, 2014), 339.

23. On these Muslims who were sent to the capital, see Onuma Takahiro, 250 Years History of the Turkic-Muslim Camp in Beijing (Tokyo: NIHU Program Islamic Area Studies, 2009).

24. These men all belong to the line of Khoja Karamatullah, second son of Muhammad Yusuf. 
Sarimsaq: The official Haiming got this individual out from Kashgar and sent him to the capital. ${ }^{25}$

'Așim, 'Abd al-Khaliq, and Baha' al-Din: The official Sinju brought these three back from Badakhshan and sent them to the capital.

Muhammad Emin: This individual remained in Badakhshan. Later he escaped and went to a more distant place called Imam 'Ali. ${ }^{26}$

\section{The Origins of the Various Burut of the Outer Regions}

The Burut are Muslims who nomadise in the mountains. Although their dress differs from that of the Muslims who live in cities, they share the same religion. Their way of life is slightly different from the Muslims. Upon investigating their origins, [we learn that] they too are people from Bukhara. Because there were too many people and land was limited, there was not enough room for them all, and conflicts over land continuously broke out. The common people, who could not bear the hurt that they were suffering in the chaos, scattered in various directions. For over three hundred and thirty years now, they have been eking out a living in the mountains by relying on a few horses and livestock, and by hunting.

Throughout this period they continued to dwell within the mountains, avoiding the instability. As they gradually multiplied, they ran out of space to hunt collectively and again fought among themselves for land, only barely obtaining enough clothing to wear. At this point, they developed the custom of raiding passing merchants. Yet as they were constantly quarrelling with each other, they derived no profit [from this], and some two hundred and twenty years ago they took council and reconciled. They apportioned the households equally and split into two divisions. They selected a couple of wealthy men and appointed them as the two leaders, and indicated the lands, rivers, and mountains that each would occupy. In this way they divided into two branches, north and south. They called those in the south the Toqquz oghul [Nine Sons], and those in the north the Qirq qiz [Forty Daughters]. Within each of these original branches, they did not [further] subdivide the units that had come into being when they first entered the mountains, but as time went by they assigned different home territories according to the pasturage and rivers of the mountain valleys. They borrowed the names of the lands

25. In 1761, Haiming submitted a report to the Qing court to the effect that he had captured Sarimsaq, believed to be Burhan al-Din's son.

26. This is the real Sarimsaq, Khoja Burhan al-Din's son. Note that the Chinese gloss errs here in reading Manchu casi ("beyond, in that direction”) as part of the toponym, and the final consonant as /n/ not /l/, giving 察仕伊瑪門. The form Imamul/Imamal occurs frequently in the Manchu archive for this toponym, which must refer either to Mazar-i Sharif (believed by some to be the resting place of Muhammad's cousin and son-in-law, 'Ali) or Hażrat Imam, in the district of Qataghan. 
and mountains that they occupied to give names to each tribe. None were to transgress the borders that had been defined, and they ceased harming each other within each territory.

Although in this way they obtained a degree of stability, as they were not well versed in the teachings of the Muslim religion, the common people were not subject to restraint, and they could not obtain mutual trust and harmony. They continued to block off the various roads and waylay the Muslim merchants who were coming and going, and remained intent on ill-gotten gain. In so doing they obstructed the trade routes of the Muslims of the various lands and prevented commerce from flowing. In response, the Muslims mobilized in great numbers and set about driving them away and plundering them. [The Burut] harbored a grudge at this, and so each autumn the Burut would take advantage of the time when the horses and livestock were fat, combine in force, and suddenly emerge from the mountains and raid the Muslims. With the plunder that they took, they would survive the winter.

The Muslims are by nature docile and weak. The pasturage in their territory was also of poor quality, and their horses were not strong. Thus they could not easily resist [the Burut raids]. Even if some of them banded together and sought to take revenge, the Burut were familiar with the mountains and accustomed to the cold. The horses and livestock found it difficult in the pervasive snow and ice. Whenever [the Burut] found out that the Muslims were approaching, at first they would not resist. They would set people in ambush in a suitable place, and after sending out a few troops to confront [the Muslims], they would entice them to enter into either a steep mountain range, a remote and impenetrable desert, or a narrow valley. Then suddenly they would press from the flank and attack. As if they were hunting, they would tire out and destroy the enemy without expending any energy. But they would not wipe them out entirely. They would keep the healthy women, and they would allow the wounded and crippled survivors who were left straggling on foot to get back to their homeland, so that they could grow the crops that they would raid in later years.

Since the Muslims were extremely widely dispersed, even if they suddenly attacked in great numbers and struggled with all their might, they simply satisfied a desire for revenge, without obtaining any benefit at all. As it was impossible for them to permanently station a large garrison there, the tradition of raids taking place each autumn persisted. When they realized that the Burut were coming, they would rush about and get into their defensive positions. If [the Muslims] kept guard well, they would not let them get beyond these shelters. If [the Burut] carried off the grain and such things that were left outside, [the Muslims] would count themselves lucky.

Ever since the Central Nation pacified and brought the Muslims to submission, they have become servants of the emperor who rules all under heaven, and the Burut have not dared to encroach. One by one, they have become civilized and submitted in 
crowds with bowed heads. They have observed the law and religion, maintained order, and with pride and loyalty they have accepted their happy fate to live in this age of the Holy Emperor. They have now put raiding and plundering behind them and have allowed the highway of commerce that leads from within the realm to the outside world to flow smoothly and free from interruption. Should [a merchant] pass through someone's territory, they even take care of them before sending them on their way.

It must be pointed out that the Holy Ejen's merciful instruction envelops all under heaven, and there is no thing in existence that it has not directed towards the good and set straight. Even the people of the few small tribes who dwell in the nooks and crannies of the very remote snowy mountains no longer form raiding parties. None of these wild tribes dare to trespass the frontier and raid, fearing that they are not strong enough [to do so]. Now they each subsist on the small grasslands located in the mountains and valleys where they nomadise, and they make a living hiding away, following the rivers to their source. Because their territory does not produce anything at all, the Muslims do not go there, and they are not in communication with the main routes leading through the various lands. Their way of life is still poor, but they do not engage in conflicts. They have all settled in the hideaways and crooks of the mountains and valleys neighboring the various Muslims and Burut. <The Burut do not plant crops. What they depend on is the grain of the Muslims and the flesh of the wild animals that they catch by hunting. They wear pelts. They live by selling the horses, cows, and sheep that they have bred and by buying Muslim foodstuffs and textiles. If some tribe's animal husbandry is of poor quality and they cannot obtain things to trade for foodstuffs and textiles, then one must perpetually be on guard against their surreptitious raiding.

Having now remedied [the issue] of internal conflict breaking out at the point where there is not enough room for them to hunt collectively,> we have outlined the origins of the tribes included within the two northern and southern branches of the Burut and the names of all the biys who lead them (a biy is the name of an official), and we have indicated what we determine to be the approximate number of households.

[(XYDLTS) The people belonging to Maḥmud Qulï of the Sayaq and Sarïbaghïsh Burut, numbering up to two thousand households, grow crops and nomadise in Komak Tepe. The nine tribes subject to these are the following:

1. The people belonging to Sirbak of the Sayaq Burut, numbering more than five hundred households.

2. The people belonging to Habken of the Asik Sayaq Burut, numbering more than five hundred households, grow crops and nomadise in Shoman Su.

3. The people belonging to Tülik Biy of the Chekir Burut, numbering up to four hundred households] (XYZ), grow crops and nomadise in Jum- 
gal. ${ }^{27}$ The more than two hundred households belonging to Ming Ilha grow crops and nomadise in Terek. Temuryan's people, numbering more than one hundred households, grow crops and nomadise in Tuyuhuyar.

4. The people belonging to Polat of the Saribaghïsh Burut, numbering more than two thousand households, grow crops and nomadise in Üch Tash and Maral.

5. The people belonging to Cherikchi of the Buhei Burut, numbering more than six hundred households. They grow crops and nomadise during summer in Yucuheike. They grow crops and spend the winter in Shargarlam, and they breed cattle in Yambulaq.

6. The people belonging to Bayastan of the Baghïsh Burut, numbering up to five hundred households, grow crops and nomadise in Maral.

7. The people belonging to Murat of the Bassïz Burut, numbering up to two hundred households, grow crops and nomadise in Alabug a .

8. The people belonging to Haji Biy of the Monggoldor Burut, numbering more than three hundred households, grow crops and nomadise in Boron$\mathrm{du}^{28}$

9. The people belonging to Jaomarat of the Juncirik Burut, numbering more than six hundred households, and Shadzang's of more than four hundred households, grow crops and nomadise in Atbashi. The two tribes subject to these are:

A. The people belonging to Yoldubai of the Besh Tamgha Burut, numbering more than three hundred households, grow crops and nomadise in Bashi Su.

B. The people belonging to Beimet of the Asak Burut, numbering more than two hundred households, grow crops and nomadise in Ombisitan.

The people belonging to Yamansara of the Solto Burut, numbering up to six hundred households, grow crops and nomadise in Susamir. Nisha's people, numbering more than three hundred households, grow crops and nomadise in Qaraqol.

The people belonging to Narbuta of the Qushchu Burut, numbering more than six hundred households, and 'Ubaydullah's people, numbering more than three hundred households, grow crops and nomadise in Jergital, Alaktuhun, Kaidar An, and On Arcak. Subject to these are the people of Coboo of the Yuvash Burut, numbering up to two hundred households, who grow crops and nomadise in Aksai.

27. Tülik Biy submitted to Jaohūi's officers in Jumgal in 1758, the first Kirghiz leader to do so. See Imbault-Huart, Recueil de documents sur l'Asie Centrale, 153.

28. The Manchu text in the XYDLTS ends at this point. 
The people belonging to Jiyambek of the Qïtay ${ }^{29}$ Burut, numbering up to two thousand households, grow crops and nomadise in $\mathrm{Kunci}^{30}$ and $\mathrm{Chu}$-Talas. The three tribes subject to them are:

1. The people belonging to Maitak of the Qushchu Burut, numbering more than 1,500 households, who grow crops and nomadise in Talas and Aktubak.

2. The people of Haraboldu of the Qitay Burut, numbering more than 1,200 households, who grow crops and nomadise in Talas, Qara Bulaq, Yurumaral, and Kunci.

3. The people of Khoja Quli of the Saruu Burut, numbering more than five hundred households; Shah Batur's people, numbering more than four hundred households; and Jambal's people, numbering up to four hundred households, who grow crops and nomadise in Kümüsh Tagh in Talas. ${ }^{31}$

The people belonging to Haji Biy of the Adigine Burut, numbering up to eight hundred households, spend the winter in the city of Osh and spend the summer growing crops, raising livestock and nomadising in Wama, Muyun, Guidahuna, and Jumbais. The eight tribes subject to them are the following:

1. The people belonging to Oljitai of the Khurumshi Burut, numbering up to one thousand households, and those belonging to Tinibek, numbering up to two hundred households, grow crops and nomadise around the town of Özgand.

2. The people belonging to Khoja Biy of the Joru Burut, numbering up to five hundred households, grow crops and nomadise in the village of Korpa.

3. The people belonging to Atabuta of the Arday-Manaq Burut, numbering up to three hundred households, and those belonging to Juma, numbering up to two hundred households, grow crops and nomadise in Alim Tübe, Ajibek, and Manak.

4. The people belonging to Atnahuli of the Börü Burut, numbering up to three hundred households, and those belonging to Bay Khoja, numbering up to two hundred households, grow crops and spend the winter in the village of Arman. They grow crops and spend the summer in Kairma.

29. The Manchu Hetaikuci looks to be a compound tribal name; it may indicate "Qiitay and Qushchu," or "Qïtay-Qipchaq."

30. Note that Suprunenko (Materialy, 82) interprets this toponym as Küngäy, i.e., the branch of the Tianshan to the north of Lake Issiq Köl.

31. The ordering here differs from the XYDLTS, which puts the Saruu between the Baghïsh and Bassïz, i.e., subordinate to the Sayaq and Saribaghïsh. 
5. The people belonging to Qurbantai of the Bargï Burut, numbering more than three hundred households [ ... ]

Within the mountains to the north of this region, there are [members of] the southern branch [of Burut], and in the mountains to the south, there are [members of] the northern branch. When we tried to ascertain the reason for this, everyone said that previously when they split up into branches and robbed the merchants among their Muslim subjects, when those subordinate [Muslim] leaders came looking for them to exact revenge, [the Burut] withdrew and migrated chaotically before settling. As this went on for a long time, [the Burut] grew accustomed to this way of life and did not return to their original territories. Now they have all ended up living alongside one another. Nonetheless, the leading groups who rule them, since they still nomadise in the places they originally chose for themselves, have been recorded as follows:

[These are] the leading tribes of the branch known as the Southern Toqquz Oghul: Qïpchaq, Qarategin, Baghïsh, Adigine, Börü, Nayman, Joru, Teyit.

[These are] the leading tribes of the branch known as the Northern Qiirq Qïz: Sayaq and Sarïbagïsh, Qitay, Saruu, Monggoldor, Solto, Yuvash, Munduz, Bassïz, Qushchu, Cherik.

\section{Works Cited}

Brophy, David. "High Asia and the High Qing: Persian Letters in the Beijing Archives." In No Tapping around Philology: A Festschrift for Wheeler McIntosh Thackston Jr.'s 70th Birthday, edited by Alireza Korangy and Daniel J. Sheffield, pp. 325-67. Wiesbaden: Harrassowitz, 2014.

Fletcher, Joseph F. "The Naqshbandiyya in Northwest China." Edited by Jonathan N. Lipman. In Studies on Chinese and Islamic Inner Asia, edited by Beatrice Forbes Manz, pp. 1-46. Aldershot: Variorum, 1995.

Fu-heng 傅恆, comp. Qinding huangyu Xiyu tuzhi 欽定皇輿西域圖志. Taibei: Wenhai chubanshe, 1970.

Imbault-Huart, C. Recueil de documents sur l'Asie Centrale. Paris: Ernest Leroux, 1881.

Kim, Hodong. "The Early History of the Moghul Nomads: The Legacy of the Chaghatai Khanate." In The Mongol Empire and Its Legacy, edited by Reuven Amitai-Press, and David O. Morgan, pp. 290-318. Leiden: Brill, 1999.

Kim, Kwangmin. Borderland Capitalism: Turkestan Produce, Qing Silver, and the Birth of an Eastern Market. Stanford, Calif.: Stanford University Press, 2016.

Melnalksnis, A. I., and I. K. Glagoleva. Opisanie kitaiskikh rukopisnykh knig i kart iz sobraniia K. A. Skachkova. Moscow: Nauka, 1974.

Mokeev, A. M. "Dual'naia etnopoliticheskaia organizatsiia kyrgyzov na Tian'-Shane v XVI - seredine XVIII v." Tiurkologicheskii sbornik 2007-2008 (2009): 258-72. 
Mosca, Matthew W. "Cišii's Description of Xinjiang: Its Context and Circulation." In Xinjiang in the Context of Central Eurasian Transformations, edited by Shinmen Yasushi, Onuma Takahiro, and David Brophy. Tokyo: Tōyō Bunko, forthcoming.

Norman, Jerry. A Comprehensive Manchu-English Dictionary. Cambridge, Mass.: Harvard University Asia Center, 2013.

Onuma Takahiro 小沼孝博. 250 Years History of the Turkic-Muslim Camp in Beijing. TIAS Central Eurasian Research Series, vol. 2. Tokyo: NIHU Program Islamic Area Studies, 2009.

. "Saiiki chiri zusetsu' shoshū no chūō Ajia shobu ni kanren suru Manbun kiji ni tsuite" 『西域地理図説』所収の中央アジア諸部に関連する満文記事について. In Min Shin ryōchō no 'han' seisaku no hikaku kenkyū 明-清両朝の「藩」政策の比較研究, edited by Kataoka Kazutada 片岡一忠, pp. 66-81. Report of the Scientific Research Project Grant-in-Aid JSPS, Basic Research (B) (2), Subject no. 12410093. Tsukuba: Tsukuba University, 2004.

Ruan Mingdao 阮明道, ed. Xiyu dili tushuo zhu 西域地理图说注. Yanji: Yanbian daxue chubanshe, 1992.

Suprunenko, G. P. Materialy iz kitaiskikh istochnikov po istorii kirgizov XVIII-nachalo XIX vv. 1976. Rukopisnyi fond Natsional'noi Akademii nauk Kyrgyzskoi Respubliki 5179.

Yunggui 永貴. Huijiang zhi 回疆志. 8 juan. Shunde Li shi, 1893.

Yunggui 永貴 (?). Xiyu zhi 西域誌. 12 juan. Russian State Library, Department of Manuscripts, No. 287/445/1-3. 1968. 